\title{
Collaborative team teaching
}

\section{Shayne Walker}

Shayne Walker (Ngai Tahu, Ngati Kahungunu) is a lecturer in the Department of Social Work and Community Development at the University of Otago.

E raka te maui, e raka te katau (he tangata ano ma te maui, he tangata ano ma te katau) 'The right hand is adept, the left hand is skilful (some people attend to the left, some people attend to the right)

\section{Introduction}

An academic career at Otago University is premised on the idea that we come pre-packaged for teaching, research and community service. In an ideal world this may be so, but in our experience as Maori academics in an applied professional department, this has not been the case for a number of reasons. Firstly, rather than come primarily through the academic system, the lecturing staff in our department come from an applied/professional background where most of us have worked as professional social or community workers. Therefore, our participation in the university system brings with it an enormous amount of practical experience in the fields we are teaching. However, it often lacks some of the key elements important to an academic institution. Developing the knowledge and skill base to undertake research, teaching and community service, especially when you consider professional development, promotion, remuneration and now PBRF, seems like an insurmountable task at times. Our approach has been to develop these things in a way that suits us culturally, personally and academically.

Therefore, this paper will explore some of the reasons and subsequent implications for why we have chosen to work collaboratively and team teach all our papers. For the purposes of this paper we will discuss: ways of knowing; ways of viewing; complementarity of skills; experiential and knowledge bases; collegial relationships; and workload implications.

\section{Ways of knowing}

It is important to note at this stage that the teaching and learning of knowledge is not an acultural experience, therefore the knowledge taught may be implicit within the mode of delivery and will affect the outcome, i.e. the subsequent wisdom from the knowledge gained.

We attempt to follow a kaupapa (agenda / philosophy) of Maori indigenous approaches. Bishop (1996), citing Graham Smith, describes this as:

... the philosophy and practice of 'being and acting Maori' (p.1). It assumes the taken for granted social, political, historical, intellectual and cultural legitimacy of Maori people, in that it is a position where 'Maori language, culture, knowledge and values are accepted in their own right' (p.13). Further Kaupapa Maori presupposes positions that are committed to a critical analysis of the unequal power relations in our society. These include rejection of hegemonic belittling, 
'Maori can't cope' stances, together with a commitment to the power of conscientisation and politicisation through struggle for wider community and social freedoms (Smith 1992, p.26).

Kaupapa Maori is not an attempt to create another grand narrative, as a 'Maori perspective', or counter-narrative (Bishop 1996), but it provides its own pedagogical framework that is valid in its own right. Kaupapa Maori has been used in the 'deconstruction of those hegemonies which have disempowered Maori from controlling and defining (researching) their own knowledge within the context of unequal power relations in New Zealand' (Bishop 1991a). This deconstruction could be viewed as a counter-strategy of 'writing back' to the West (Tuhiwai Smith, 1999). In our view part of that writing back has to do with how we go about teaching in this environment.

Said, cited in Tuhiwai Smith (1999), refers to the 'Western discourse about the other' as the process by which knowledge regarding indigenous peoples was 'collected, classified and then represented in various ways back to the West, and then, through the eyes of the West, back to those who have been colonized' (Tuhiwai Smith, 1999, pp.1-2). In regards to teaching and learning in an indigenous context, it is important to have an understanding of the sophisticated ways in which the quest for knowledge is deeply embedded in the many layers of imperial and colonial practices (Tuhiwai Smith, 1999). Our team teaching approach, whilst part of the an imperialist system, also deconstructs it.

Bishop (1996), citing Olsen (1993, p.5), discussed French post-structuralist Michel Foucault's (1980) ideas of 'the productive function of power-knowledge' which is to 'regulate populations by describing, defining and delivering the forms of normality and educability'. In other words, if you have the power to define you can define what is knowledge, essentially through the production of grand narratives that may in turn be used for normalisation, interpretive potentialities or oppression (Bishop, 1996). In Aotearoa/ New Zealand research has specific implications for teaching and learning. Therefore, we team teach as a practical way to illustrate a philosophical approach that limits 'the productive function of power-knowledge' in the day-to-day teaching of students, by offering different perspectives, personalities, skills and experiences.

\section{Ways of viewing}

The University is a Pakeha-dominated environment where concrete thinking in terms of Maori issues are relegated to an expectation that there is one Maori way of doing things. This is especially apparent in the academic content of papers that, for want of a better term, include a Maori perspective. In our discipline which is social and community work education, our students often think that if they get 'the' Maori perspective nailed then they can go out and do the business and be competent to work with Maori. So having complementary skills and knowledge bases that are sometimes conflicting can unsettle their 'concrete' thinking. Diverging opinions give them less confidence to go out and work with our people and this is a good thing because it is more likely they will seek help.

We seek to challenge the arrogance and presumption we have encountered in the social work profession, where we know of a social worker who declared that because they had studied a Maori language paper and a Maori society paper, that they had a 'right to work with Maori families'. 
We have also found team teaching useful theoretically, as we pro-social model many of the theoretical approaches we teach. For instance, if post-modernism and post-structuralism is about multiple positions, flow, flux and fragmentation, then we as Maori are just as guilty of slipping back into modernist approaches where 'the Maori way' becomes a grand-narrative that our students can use to normalise and affect the potential of their eventual Maori clients. You may be wondering, is this really important? In our experience it is. The bulk of our students are Pakeha and they can write fantastic essays for us but when they see an item on the news on a Maori issue, what are their reference points? Do they have the tools to unpack the layers and agendas of that particular news item? We are sure that multiple views and approaches to issues especially where we disagree can only add to their intellectual rigorousness.

\section{Complementarity of skills}

In 2000 I had been at the University for three years as part of a Ngai Tahu-based mana whenua team. Anaru came on to the staff with a strong community background, initially to fill in for a year while another Ngai Tahu Maori staff member went on sabbatical. I was determined that Anaru would get a fair go - so the team teaching approach started initially as mentoring and support, to ease him into the role of university lecturer.

This was not the first time we worked together. We had both worked as volunteers for the same organisation in 1980-81, then in 1982, we trained together as youth workers for a year, with me staying in Dunedin and Anaru moving to work in South Auckland.

One of the reasons we enjoy working together is because of the complementarity of our skills. Without sounding too sickly, we go together as a part of a team that truly does complement one another. We each have different approaches to issues of detail, substance, presentation and confidence. One is an extrovert and the other is not; Anaru enjoys researching the detail and is interested in the process whereas I am interested in the outcomes or conclusions. As our working relationship developed, we discovered more of our skills, strengths and weaknesses along with an honesty to be able to discuss them and act accordingly. We can be teina or tuakana to one another in different situations and we don't mind, although Anaru likes going first when we teach otherwise he may not get enough time. Our personalities complement this process and we have never thrown our toys at each other. Even though there are times we may get frustrated it doesn't matter because we'd rather do it together than on our own. Some may think 'harden up, develop your own skill base this is a co-dependency-based cop out'. Not so, our teaching load at the moment is at least twice that of some of our colleagues and on our own this would not be the case.

\section{Experiential and knowledge bases}

Anaru's background is such that our department at the University is the first time he has worked outside the Maori community since 1981. Personally, politically and in a familial sense he has had quite a different experiential and subsequent knowledge development pathway than me. Anaru has been involved in many Maori organisations and has a strong interest in community development. He and his wife Margaret have raised their kids through kohanga and kura and the involvement this entails. Having lived back in Tainui has affected the way 
that he sees the world and behaves in it. In 1994 he moved back to Dunedin working as a Maori health promoter learning a lot about working in the community, building alliances and supporting Maori development wherever he saw it and beginning his university studies at age 32 .

I on the other hand was orphaned at 12 years old. I was raised by my mother's family, before the State took over when they couldn't cope with my behaviour and I became a Ward of the State, spending time in various institutions and foster homes etc. To cut a long story short I married Helen at age 20 and started working for a Christian Maori organisation and got our first whangai eight months later. We sent our three children to Catholic schools. We fostered 192 young people and I directed a child and family service and worked as a community-based child protection/youth justice social worker. I also found myself studying at university at age 32 and four years later when a staff member went on sabbatical I was asked to lecture their papers and the rest is history.

Why are we telling you this? We believe that the personal is professional and that our differing experiential and knowledge bases adds to our teaching in a way that weaves a rich and creative tapestry from which our students can grow. The last time Michael King was interviewed his catch phrase was 'context is everything'. We believe that team teaching not only sharpens up our views but also challenges many of our students to develop a professional approach that can encompass and encourage multiple viewings of issues and client-based situations.

This has become especially apparent when dealing with Mana whenua and Maata waka issues. In our presentations our whakapapa and familial allegiances come into play, we champion both and we cannot help it. I am Ngai Tahu/Kahungunu and Anaru is Tainui, we model both sets of rights, roles and responsibilities. We stress that 'so called' Maori rights are not Maori rights at all but derive from participation as hapuu and iwi. For example, Anaru as Tainui doesn't have any rights to the fish in Te Waipounamu (inside the 12 mile limit, a good point of contention and good natured ribbing). Again this set of diverging viewpoints can only add to student learning.

\section{Collegial relationships}

Whakawhanaukataka has implications in terms of the reciprocal nature of relationships. Our ability to be collegial is sharpened when there are at least two of us in collegial forums etc. We watch each other's backs and provide mutual support in what is sometimes a hostile environment. We both think that hunting as a pack is important, where because there are at least two of us, it is harder for those who would want to marginalise us.

There also needs to be a place for black humour where we can laugh, argue and grieve over the things that come out of a Maori worldview. Our experiences in this environment has taught us that if an institution is going to employ Maori academics, then they shouldn't just employ one; the chances of good Maori staff retention rates improve if there is a critical mass and therefore more than one of us.

Within many departments Maori staff are often seen as having the answers to so-called Maori problems. It can be a look or an insinuation but the expectation is often still there, 
and not malicious. Critical mass can affect the nature of being treated as the 'other' and in fact others start to deal with their own Treaty/Cultural issues.

We do not agree with cultural advisors being appointed to departments unless they are appointed as full academics, otherwise they are employed on 'general staff' fixed-term contracts often in a marginalised position even before they start working. It is a sad fact that administrative staff are often not treated with the same level of respect by academics particularly when their position can be seen as a token one.

We have found that working together as academics means that we are taken more seriously in the university environment, and being Maori academics means that our value has increased particularly with the focus on PBRF.

\section{Workload implications}

While our approach may sound attractive to some, it does have negative implications. Our workload is such that it at times makes things very difficult. There is the problem of continual tiredness as we still have to conduct our research and be involved in community service, all this while completing our own studies.

When we persisted with our form of teaching after the initial mentoring phase, we were told by the University hierarchy that we could continue, but were warned that there would be personal costs in this; how right they were. The continued pressure, particularly to perform for PBRF, is making this approach more and more difficult to achieve.

Unless we can do something about our workloads the future for us working as a team will be difficult, but our commitment to the kaupapa, the students and each other demands that we do some work to make it happen.

\section{Conclusion}

The major problem of this approach is its sustainability. Extra resources are needed, and this is not for the Maori students, as Maori already know the things that we are discussing. No, it is so that Pakeha get a better understanding of Maori diversity and processes.

We believe that team teaching is a process that benefits Maori and Pakeha. It benefits our Pakeha students because not only does it challenge a monocultural view of the world, but it directly challenges the desire to reduce social work with Maori to ticking off a checklist. We have found that Maori students also benefit from this approach, where we become part of the normalising of Maori success within the institution.

It benefits the institution as it creates more substantive outcomes, and shifts away from tokenistic attempts of political correctness, to one that fosters and supports Maori development and advancement.

It benefits us, the lecturers, as it creates an atmosphere where we feel that we too are owners and stakeholders within the institution and allows us to grow, develop and create as we sharpen our views, processes and logic. 
The opportunity to work together, complimenting our skills, experience, tribal origins, personalities, teaching and researching styles has been a privilege.

In summary, the right hand is adept and the left hand is skilful and they know it!

\section{References}

Bishop, R. (1991). He Whakawhanaungatanga tikanga rua: Establishing links: A bicultural experience. Unpublished Masters thesis, Department of Education, University of Otago.

Bishop, R. (1996). Collaborative stories as kaupapa Maori research. Palmerston North: Dunmore Press.

Foucault, M. (1980). Power/knowledge - selected interviews and other writings 1972-1977. New York: Pantheon Books.

Tuhiwai Smith, L. (1999). Decolonizing methodologies research and indigenous peoples. Dunedin: University of Otago Press.

Williams, H. (1975). A dictionary of the Maori language. Wellington: A.R. Shearer, Government Printer. 